\title{
The postcolonial politics of dignity: From the I 956 Suez nationalization to the 20 I I Revolution in Egypt
}

\section{Zaynab El Bernoussi}

Al Akhawayn University, Morocco

\begin{abstract}
This article is a study on dignity and the politics of dignity in postcolonial Egypt, and focuses on the historicity and socioeconomic background of two events: the 1956 Suez Canal Crisis during the rise of post-independence nationalism and the 20I I Egyptian Revolution during the Arab Spring. This study reviews the importance of the concept of dignity in philosophy and the social sciences, specifically pertaining to the development and postcolonial need for dignity and recognition, which the author terms 'dignition.' The central question here is how the conception of dignity has evolved between the two events and what the implications are for the consequent understanding of dignity.
\end{abstract}

\section{Keywords}

Development, Egypt, historical sociology, philosophy, politics of dignity

\section{Introduction}

This article uses Egypt as a case study to examine the colonial origins of a need for dignity in a postcolonial society. By examining and comparing Egypt's past to its present, the politics of dignity and the discourse of dignity that have figured prominently are elucidated. Methodologically, it is a study in historical sociology, as conceived by Charles Tilly, in that:

\footnotetext{
Corresponding author:

Zaynab El Bernoussi, Al Akhawayn University, School of Humanities and Social Science, PO Box 104, Hassan II avenue, 53000 Ifrane, Morocco.

Email: z.elbernoussi@aui.ma
} 
Historical social criticism reconstructs the past on the way to informing human choices in the present and future. It rests on the plausible assumptions that history contains a record of human successes and failures in dealing with problems persisting into the present; that if long-term trends exist, their causes are likely to continue; and that recent history limits what will happen next. (1980: 100)

This study carries a postcolonial sensitivity and is explicitly engaged with postcolonial theory. As cultural critic and historian Robert Young noted, 'postcolonialism claims the right of all people on this earth to the same material and cultural well-being' but he also pointed to the fact that 'the reality, though, is that the world today is a world of inequality, and much of the difference falls across the broad division between people of the west and those of the non-west' (2003: 2). Further inequalities can be seen in postcolonial societies, giving rise to what this study suggests is a greater demand for dignity and recognition. It is, therefore, important to focus on how the conception of dignity evolved and how much it connects with the social and political change in postcolonial Egypt.

\section{Egyptian context}

European interest in Egypt escalated after the brief Napoleonic colonization from 1798 to 1801 . When the French were expelled from Egypt by the British and Ottomans, they 'left behind a confused situation in which it was possible for the commander of the Albanian forces nominally in the service of the Ottoman governor to rise to power in 1805' (Hopwood, 1982: 9). The Muhammad Ali dynasty of Albanian origin established a foreign dictatorship that ruled over Egypt and Sudan. Muhammad Ali was respected for his economic contributions and for allowing certain independence to Egypt from imperial powers. He introduced a number of reforms and worked for an economic revolution by building factories, digging canals, and introducing cotton cultivation in the Delta (Hopwood, 1982). It was his fourth son, Said Pasha, who bought the schematics for building a canal across the Isthmus of Suez from French engineer, Ferdinand de Lesseps.

The construction of the Suez Canal was initially funded by the French and Egyptians, but in 1875 due to Ismail's financial irresponsibility, ${ }^{1}$ the Egyptian shares were purchased by the British government under Benjamin Disraeli (Hopwood, 1982: 10). This strengthened British interest and European influence in Egypt, ultimately resulting in increased discontent among the local population. This came to a head in July 1882, at the battle of Tel El-Kebir, when a British fleet bombarded Alexandria and defeated Ahmad Orabi, one of the first Egyptian nationalist heroes. However, nationalism actually soared in the face of this assault, and as Middle Eastern bibliographer Derek Hopwood explained: for Egyptians, the period of British rule was a time of 'humiliation, a negation of dignity' (Hopwood, 1982: 12, emphasis added). Furthermore, that feeling of humiliation was further exacerbated by a foreign dictatorship, which in this case was the Muhammad Ali dynasty.

In the 1952 revolution, the last king of the Muhammad Ali dynasty, Farouk I of Egypt, was toppled by a group of army officers, among whom was Gamal Abdel Nasser. He became the second President of Egypt after Muhammad Naguib, the leader of the 1952 
revolution. ${ }^{2}$ Nasser was immediately seen as a threat by western powers and British Prime Minister Anthony Eden even considered him a fascist (Kyle, 2011 [1991]: 184). There were many attempts to assassinate him as well. Despite these threats, Nasser grew to become one of the most venerated leaders in modern Egypt, as well as an indispensable figure for Arab nationalism and dignity. Among his many projects was the Aswan Dam, a pivotal project for Egypt's industrialization. However, the US withdrawal of financial support from the Aswan Dam, perceived as a retaliation to Nasser's policy of neutrality, left Nasser needing an alternative funding solution and led to the founding of the Non-Aligned Movement, an organization based on ideological independence and human dignity.

The Aswan Dam project became the main trigger for the Suez Canal Crisis. Indeed, for the construction of the dam, Nasser needed money and the tolls from the Suez Canal were an attractive source. Thus, the nationalization of the Suez Canal became his priority. This initiative, however, was a direct challenge to the US Secretary of State John Foster Dulles, as it threatened his regional allies. Ultimately, in an effort for consistency, the United States decided not to intervene, in line with its decision during the anticommunist protests in the 1956 Hungarian Revolution against the Soviet Union. During the Suez Crisis the Anglo-French attack on Egypt was seen as a blatant imperial assault and a test of Egyptian dignity. It challenged Nasser's attempt to materialize the Egyptian people's dignity in their right to control the canal. At the end, the Egyptians stood firm to the imperial attack and remarkably, sparked domestic protests in which French and British civilians condemned their own governments.

After the 1956 Suez Crisis, Egypt fought six subsequent wars in the region and intensified the political instability in the area. Egypt's economy has been based on centralization, since Nasser's intense nationalization policy and the wars fought increased the country's external debt. During the 2008 global financial crisis, the country's financial situation only worsened with soaring food prices. The precariousness of Egypt's poorest increased and further destabilized the social infrastructure. Egyptian anthropologist Mohamed Tabishat was among the scholars who thought that social inequality and political oppression targeting the Muslim Brotherhood from Nasser to President Sadat and Mubarak was doomed to explode in some sort of revolution for change. Triggered by the Jasmine Revolution in Tunisia, the Egyptian Revolution toppled the Mubarak regime in 2011. This was a revolution without political leadership. Sociologist Mohammed Bamyeh was in Egypt during the events and recalled:

Over the days I saw an increasing demographic mix in demonstrations, where people from all age groups, social classes, men and women, Muslims and Christians, urban people and peasants - virtually all sectors of society, acting in large numbers and with a determination rarely seen before. ${ }^{3}$

Since the advent of the Arab Spring, increasing instability has reigned over the region, where governments and regimes have continued the cycle of dismantling and assembling. However, a discourse for change and dignity has also blossomed, as demands 'clustered around the respect for the citizen, dignity, and the natural right to participate in the making of the system that ruled over the person' flourished. ${ }^{4}$ 


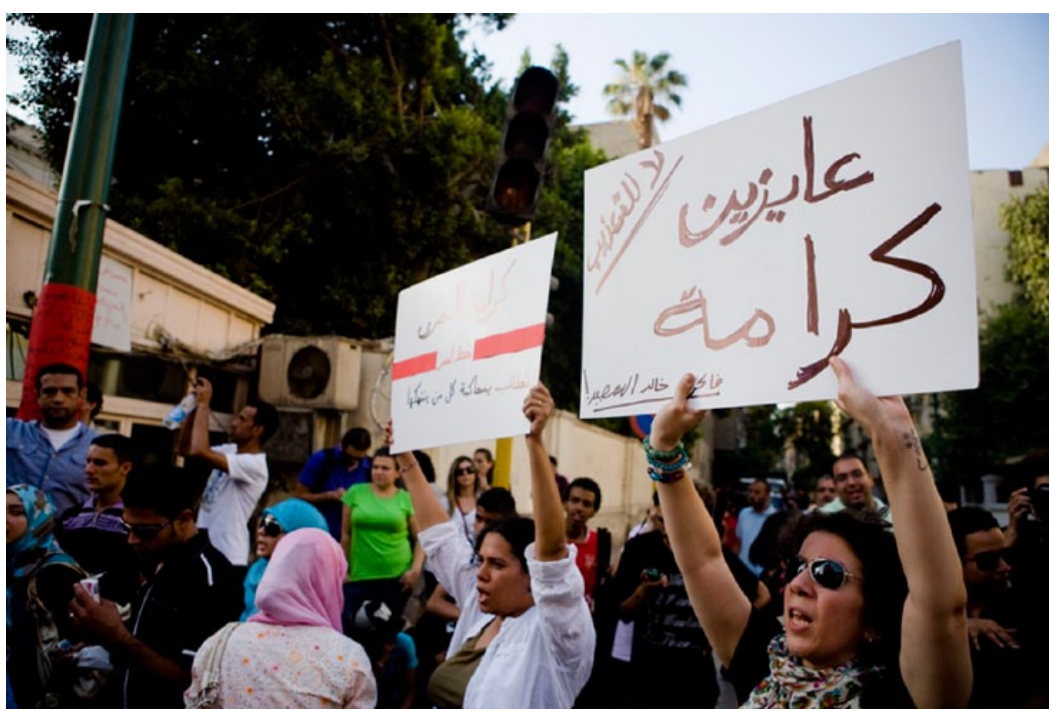

Figure I. Egyptian woman showing a poster that reads 'we want dignity' - karama (كر امة). Source: arabawy.org

For Egypt during the Arab Spring, the events of the revolution started on 25 January 2011, called the 'Day of Rage,' when tens of thousands of people gathered peacefully in Tahrir Square demanding the stepping down of then President Hosni Mubarak. People brandished placards of all kinds, where they had written their demands, such as the demand for dignity (Figure 1). On the very first day of protest, a journalist reported an Egyptian protester yelling: 'I want my 3-year-old child to grow up with dignity and to find a job just like the president.' 5 This is a direct and material conception of dignity. Such a conception contradicts a conception of dignity as part of the realm of selfexpression values in the context of post-materialism theory advanced by Ronald Inglehart (1971). Two weeks and three days after the 'Day of Rage,' Hosni Mubarak resigned on 11 February 2011 and crowds found themselves in tears celebrating his ouster.

Ironically, Mubarak's address to the nation before his resignation was touted as the act of a 'dignified' man. Just over a week before the overthrow, on 3 February, Mubarak's new prime minister (he had recently changed his prime minister in a reformatory attempt) stated that it was 'not common in Egyptian culture for a leader to leave without his dignity.' He went on by saying that Egyptian culture does not approve of insulting the character of the 'father' that Mubarak fulfilled for his people. ${ }^{6}$ Here one can see a conception of dignity as honor and authority that is quite far from the protester's conception of dignity as a job.

On 24 June 2012, after much transitional turmoil, the Muslim Brotherhood candidate Mohamed Morsi was declared winner of the first free election since the overthrow of the Mubarak regime. The rise of the Muslim Brotherhood came with much controversy, particularly sparked by the constitutional revisions proposed by Mohamed Morsi. These constitutional revisions focused on Sharia law and opposed the limitation of presidential 
power, which were both perceived as a regression to repressive state measures that restrain liberties and human rights. The difficulty of human rights enforcement in societies that suffered from the yoke of colonialism followed by authoritarianism is particularly apparent with the virulence of dignity calls in both 1956 and 2011. The second massive protests of 30 June 2013 marked the one-year anniversary of Morsi's presidency; the protests led to his ousting by the military and to clashes between pro-Morsi and anti-Morsi groups. The transitional government led by Egypt's army chief, Abdel Fatah el-Sisi, had by then completely undermined the Muslim Brotherhood's presidency and legitimacy.

The Muslim Brotherhood in Egypt has a long history of oppression from the Egyptian Republic, since the Egyptian Revolution of 1952. They are among the most influential Islamic movements and political organizations in the region. Founded in 1928 by Hassan al-Banna, an Egyptian Islamic scholar, they have, since then, strove for dignity. IkhwanWeb is the official Muslim Brotherhood online portal. On their website, they state that their leader, al-Banna, 'strove hard to restore the national rights and to save the Arab dignity,' and that one of their principles as a political body is to seek 'internal and external reformation, and [plant] the seeds of dignity within the souls of the citizens.' They also emphasize past repressive abuses by the Nasser, Sadat, and Mubarak regimes in Egypt, which they call collectively as the 'dark era,' and claim that these regimes served colonial interests: '[that] is how the Egyptian governments at that dark era were but tools for the British colonization, putting neither the dignity nor the freedom of the people in consideration, as long as this would satisfy their British allies. ${ }^{7}$ In the history section of the portal, they make specific reference to conditions of humiliation at the Suez Canal Company preceding Nasser's forced nationalization:

In 1928, six Egyptian workers employed by British military camps in Isma'iliyya, in the Suez Canal Zone in Egypt, visited Hassan al-Banna, a young school teacher who they had heard preach in mosques and coffee-houses on the need for an Islamic renewal. 'Arabs and Muslims have no status and no dignity,' they said. ${ }^{8}$

Asserting that one had 'no dignity' rejects a conception of dignity as intrinsic. On the contrary, this conception of dignity implies that it is something to be 'earned.' With this previous passage, one can see a similarity with the recent indigenous conception of dignity as a job during the 2011 protests in Egypt.

When looking retrospectively at the 1956 and 2011 events in Egypt, there exists a certain recurrent discourse of dignity and even ambivalence in dignity: material dignity (e.g. obtaining a job), cultural dignity (e.g. respect for a father figure), and a certain 'spiritual' dignity (e.g. 'planting the seeds of dignity within the souls of the citizens'). In 1956, the dignity discourse was clearly dominated by President Nasser. In the 2011 Revolution in Egypt, on the other hand, the discourse was marked by a facelessness of leadership or 'plurality' of guidance. Indeed, in 2011 the protests were led by 'ordinary' people from all backgrounds. No single leadership was credited in the revolution; rather, success was attributed to a number of figures. One of them was Wael Ghonim, the Google employee who was arrested and tortured for his Facebook page 'We are all Khaled Said.' The page was in remembrance of the abject torture and killing of Khaled Said on 6 June 
2010 by the Mubarak regime because of Said's online activism against corruption. Along with these figures, there was the important list of what have been coined 'Martyrs of the Revolution,' that included a long list of women, men, elderly, and children who were disfigured, raped, tortured, and killed in the midst of a call for dignity.

\section{Dignity: A lasting call?}

Many debates around dignity are associated with clinical treatments and euthanasia, or 'death with dignity.' Dr Andy HY Ho, research officer at the Center on Behavioral Heath at the University of Hong Kong, conducted a study about death and dignity in the city of Hong Kong. He interviewed people from different age groups and socioeconomic backgrounds, and found that they attached different meanings to dignity. Some associated dignity with money, privacy, belonging, or even autonomy (Ho et al., 2013). On the other hand, Robert W Fuller, a pioneer of rankism, ${ }^{9}$ denounced the abuses of corporate power and humiliation at the workplace, and he called for the creation of a dignitarian society (2006). Dignity seems to be used in different contexts and holds different meanings. Consequently, it is important to start by defining it. Therefore, a proper prerequisite for this study is first to define dignity, specifically in a philosophical grounding of the concept. Then, aspects of development studies as well as nationalism that deal with questions of dignity will be explored, followed by an analysis of the politics of dignity, in the specific postcolonial context referred to as 'dignition.'

\section{Principles and some philosophical grounding}

Craig Calhoun used the term 'prehistory of sociological theory' to refer to the origins of social theory in Greek, Roman, Jewish, Christian, Buddhist, and Islamic philosophy (Calhoun et al., 2012). In ancient times, Roman philosopher Cicero suggested the need for universal dignity in society. However, the history of humanity that ensued cumulated cases of betrayals of dignity in acts such as slavery and colonialism. Indeed, it seems that in the human experience it is hard to truly establish egalitarian systems. Dignitas, where dignity comes from, is by definition a 'non-egalitarian' signifier: it refers to an obtained rank. A discussion of rank and equality necessarily involves a debate around the concept of power: why are there systems of hierarchy given the risks of abuses of power? These transgressions often leave their victims devoid of their dignity.

Charles Taylor (1997) examines what he calls 'politics of recognition,' where he introduces a paradigm in which politics of difference grow organically out of the politics of universal dignity. So, for instance, marginalized groups must claim 'difference' to attain those 'universal' rights that were denied to them. He suggested that Rousseau was the originator of the discourse of equal recognition as means of asserting our amourpropre, meaning esteem or literally 'self-love.' Taylor also joined Rousseau in his distinction between dignity as necessary recognition and honor as a non-egalitarian value as it refers to systems of preference. For Taylor, the urgency of 'recognizing' the need for recognition is due to the harms inflected by a misrecognition or non-recognition: it put us in a false, distorted, and reduced mode of being that affects the construction of our identity. For example, Taylor talked about the impact of racism on blacks: '[their] own 
self-depreciation, in this view, becomes one of the most potent instruments of their own oppression' (1997: 75). This example can be expanded to many colonized societies that were governed by violent regimes. Algeria is a case in point, as it has been argued their system of institutionalized violence perpetuated a 'culture' of violence and harm even after independence (Horne, 2006).

Taylor referred to Hegel's dialectic of the master and slave as a cyclical process of recognition when analyzing the rise of recognition and identity discourse used by oppressed groups. He continued by moving on to a discussion on the ideal of authenticity, which for him, 'like the idea of dignity, is also partly an offshoot of the decline of hierarchical society' (1997: 78). He explained that identity is fundamentally constructed through our social roles, whereas authenticity is a way of being that is inwardly generated. This poses a contradiction between the monological tendencies in modern philosophy and the dialogical characters of human life. This holds true when one thinks about Immanuel Kant's definition of an individual's dignity as a transcending value or 'kingdom of ends' (i.e. monological) in contrast with George Herbert Mead's notion of the Self as a construction from the 'significant others,' meaning other people in the society (i.e. dialogical).

Given the importance of the Self, much stress should be placed on subjectivity in the context of dignity as recognition and the difficulty to attain 'universal' understandings of dignity. The rise of the Self in the literature of social sciences is central in critical theory and structural analysis. An important idea that has been scrutinized concerns the centrality of historical processes in 'making' subjectivity. For instance, the protesters' chants for dignity in Tahrir are perhaps the consequence of a complex historical experience that made dignity, along with recognition, an unresolved paradigm throughout history.

In Egypt, dignity calls in both 1956 and 2011 were for social equality. However, in Egypt social equality does not only concern limiting the income gap between the rich and the poor; rather, it also refers to a 'non-capital' sense of inequality between groups that are pro-West and anti-West. Discrimination and alienation can result from 'how much westernized' one is perceived to be: being pro-West can be perceived as an undignified act of a traitor, which explains a need to anchor identity with traditions and religion. Therefore, the quest for egalitarianism in dignity must also deal with such problems of subtle discriminations first.

Lastly, the controversial rapprochement between dignity and money must be further elucidated. Some people think that dignity can be bought and others are horrified by this thought. There is no doubt that in current societies money dominates. Historian Niall Ferguson tracked what he called 'the Ascent of Money' in human history to demonstrate that financial concerns are central to all major historical developments (Ferguson, 2008). In the two cases of Egyptian turmoil in 1956 and 2011, the local economy was in much distress: the Suez Crisis was due to a financial crisis that prevented Nasser from independently undertaking his Aswan Dam project, and the 2011 Arab Spring and revolution in Egypt strangely occurred immediately after a sharp increase in commodity prices and the inability of already distressed markets to adjust. In his book, Ferguson also referred to the rise of the Rothschild family of Jewish bankers who dominated the financial world. A portrayal of this family's financial story was presented in the movie The House of the Rothschild, in which the patriarch, sensing the approach of his death, called his five sons 
to instruct them on how to build a strong banking empire and 'buy' dignity (Werker, 1934). So, can dignity be bought? The material conceptualization of dignity such as land or a job is after all a form of commoditization of dignity.

\section{Dignity in the Arab world and nationalism}

We lack nothing, but dignity. (Muhammed al-Maghut, Syrian poet, 1934-2006)

When the people demand freedom, Destiny must surely respond. ${ }^{10}$ (Abu al-Qasim al-Shabbi, Tunisian poet, 1909-1934)

The 1956 Suez Canal Crisis came in the context of rising nationalism. This nationalism was in turn boosted by the birth of Third Worldism as an anti-colonial and anti-imperial project. Nasser also focused on different forms or projects of nationalism: pan-Arabism and pan-Africanism. These projects were based on the strategic location of Egypt. Moreover, nationalism is particularly important in the context of politics of dignity as it provides the platform for identity construction and self-consciousness. In 2011, the Arab Spring seemed to revive pan-Arabism, as protesters brandished flags of other Arab countries, showing Arab solidarity.

If the Arabic word for dignity, karama, comes from the Arabic word karam or generosity, then that must say something! Berber, Bedouin, and Arab hospitality has been reported by many, which reinforces the centrality of generosity in these cultures. In the arid deserts of North Africa and the Near East, generosity is, before all else, a matter of survival. Therefore, if Bedouins share their water, food, and shelter with others, it is not just a matter of hospitality but rather serious dignity. These societies also have a strong tribal authority system that goes back to the pre-Islamic era (Hourani and Ruthven, 2002) and attests to the rigidity and dominance of the hierarchical system that challenges democratic establishments. Political turmoil in the Arab world has been consequently a serious concern for security in the region and in the world. This status is sustained by the IsraeliPalestinian conflict since the end of the Second World War. This conflict has undoubtedly put forward the topic of dignity in the Arab world. Palestinian scholar Lina Jamoul presents us with an insight:

To take away people's choices, to make their livelihood completely dependent on your own political and economic needs, is a question of dignity. Loss of dignity is when the political process serves to dehumanize you, making you passive recipients of whatever crumbs your oppressor/master chooses to throw at you. Dignity is reclaimed with the powerful act of saying no. For demanding the political process to affirm your humanity, indeed for it to be based on your human needs, not to annihilate them. The cry for justice is to demand an equal balance of power; the cry for dignity is the human need for recognition, the right to be human. (2004: 581)

Egyptian scholar Abdelwahab Al Messiri wrote profusely on this topic and its significance for Egyptian and Arab issues at large. He emphasized the Israeli abuses of power and the trampling of Palestinian dignity, and how that is increasing the social marginalization in Arab societies and the associated feelings of helplessness. Yet, he demonstrated that uprisings, such as the intifadas, are actual moments of hope and expression of dignity by the Palestinian people (Al Messiri, 1989). 
Al Messiri's focus on Palestine reveals an Egyptian tradition of Arab consciousness beyond its borders. Gamal Abdel Nasser's promotion of pan-Arabism supported this Egyptian tradition. Nasser's dignity discourse in Arabic focused on using the Egyptian dialect to address his nation in a 'casual' way while using classical Arabic in more formal speeches. His mastering of Arabic was uncontestable and the several expressions he used to signify the dignity of the Egyptians, Arabs, Africans, and people of the Third World gave his speeches much of their resonance. One should not forget, in this context, that the rise of Third Worldism since the end of the Second World War was accompanied by the rise of liberation movements against the colonial and imperial rulers. Nasser was a major participant in the birth of Third Worldism during the 1955 Bandung Conference and the Non-Aligned Movement (NAM) during the 1961 Belgrade Conference.

However, Nasser's legacy of Arab nationalism, consciousness, and leadership faded away during the Mubarak regime. During the period preceding the Arab Spring, further settlements by Israel in what was left of Palestinian territories alienated groups in Egypt that were still faithful to pan-Arabism. On top of both a political and civil society divide, Egypt also suffers from a pro-West and anti-West divide. Mubarak's regime was notoriously not only pro-West but also pleasing to the West and perpetuated repressive methods against any opposition. Egyptian human rights activist Saad Eddin Ibrahim, similarly to Nasser, defied the West, but did so by challenging the US-backed Mubarak government (Ibrahim,1996). This led to his imprisonment but undoubtedly stimulated Egyptian public opinion concerning the need to defy the West to affirm the national dignity of postcolonial Egypt. This chasm between pro-West and anti-West factions in Egyptian society created not only a system of discrimination but also a crisis of identity. Taylor affirms that:

European colonialism ought to be rolled back to give the peoples of what we now call the Third World their chance to be themselves unimpeded. We can recognize here the seminal idea of modern nationalism, in both benign and malignant forms. (1997: 78)

So is dignity stemming from an identity crisis? Could dignity in the Arab context come from a revival of nationalism? This last question is particularly pertinent given that the Arab Spring uprisings revealed much solidarity among the Arab people.

\section{Dignity and development: Negotiating with the rapist?}

International development is a postcolonial idea that sparked significant controversy concerning the real benefactors from such programs. In the majority of cases, the developed countries tend to profit while the underdeveloped countries continue to be trapped in their state of poverty. In the two Egyptian events, the politics of dignity particularly targeted the poor. Even the promise of dignity was associated with material notions of money, jobs, and land. In this section, development theories will be explored to see just how they undermine the concept of dignity as self-empowerment and autonomy.

The first major problem that plagues development in postcolonial societies is the imperialist ambition of capitalism. Jean Chesneaux discussed an 'Off-Ground Capitalism' that searches for modes of production beyond borders (1991: 88). What is interesting 
though is that he deepened this 'global capitalism' debate to discuss a psychoanalytic shift towards the Global South, which seeks 'to find in the South a new historical subject which would defeat the "Great Satan" from the North' (Chesneaux, 1991: 88). Indeed, several social movements, such as Los Zapatistas, have denounced development for being disguised as 'evil' capitalism. In Jamaica: Struggle in the Periphery (1982), Michael Manley described Jamaica's social and economic struggles due to such unfavorable 'development' plans:

I have often remarked that you cannot change Jamaica if you do not change the world. I have never meant by this anything so naive as to suggest that little Jamaica could change the world. Nor do I mean that Jamaica can avoid its responsibility to itself. We must use our resources intelligently and manage them effectively. No one owes us charity nor should we wish to take it were it available. On the other hand, the system works against countries like ours. Hence it is that international economic system which we must work to change. (Manley, 1982: 65)

Michael Manley, the former Prime Minister of Jamaica, saw the struggle against imperial capitalism as a heroic process, and in the service of dignity. Indeed, such selfconsciousness of one's capabilities supports dignity as self-empowerment and autonomy.

Andre Gunder Frank argued that the main problem in the Global South is the lack of access to land, which makes productivity hard and progress even harder. Wallerstein's modern world-system also showed how capitalism became dominant and led to world inequalities as the periphery was made dependent on a prosperous and exploitative core (Wallerstein, 1996). One should keep in mind that dependency theorists such as Frank, who, regarding poor countries, stressed 'learning how their past economic and social history gave rise to their present underdevelopment' (1966: 4) differed from Wallerstein, who considered exploitation and inequalities to be not only limited to poor countries (i.e. being in the 'periphery') but to countries even within the 'core.' For Frank, underdevelopment was still generated by the very same historical process that also generated economic development: the development of capitalism itself (1966: 261-262). In the context of this study, the goal here is to put the contexts of both the 1956 and 2011 events in global perspective. Indeed, the dynamics of international relations condition the social, economic, and political development of many postcolonial societies through international bodies such as the World Bank or the International Monetary Fund (IMF).

Rather than capitalist development, Indian Nobel Prize winner Amartya Sen (who coined 'development as freedom') and Pakistani economist Mahbub ul Haq focused on promoting human development and considered people to be the real wealth of nations (Haq, 1995; Nussbaum and Sen, 1993; Sen, 1999). This is what they introduced as the capability approach, which included the work of philosopher Martha Nussbaum. Nussbaum emphasized that human dignity should be integrated in order to construct a theory for basic social justice (2009: 19). International development in its evolution towards the promotion of the capability approach and social justice is more permissive to the promotion of the concept of dignity in the international development discourse, as well as in the human rights discourse. Sen's work gave a new direction to development studies that stress the importance of creating equal opportunities for people in order to fully realize their human potential. 
In terms of development discourse, Jenny Edkins showed how certain organizations and states depoliticize the language that describes hunger, for instance, to better serve practices of aid. Edkins was worried about depoliticization of hunger and aid, because politics provide a process of constant decision-making and questioning that technology and management techniques (as associated with the process of depoliticizing) do not provide (Edkins, 2000). Hence, a question regarding politics of dignity arises: can the depoliticization of dignity bring more attention to a rise of dignity discourse? Repressive regimes seem to provide perfect platforms for depoliticization of dignity because forms of participatory decision-making are undermined. In the case of Egypt, the contexts preceding the call for dignity reveal that political exclusion, from outside (i.e. foreign policy) and from within (i.e. internal policy), created a 'depoliticized' environment that 'repoliticized' society by focusing on the politics of dignity.

In his analysis of 'The Making and Unmaking of the Third World through Development,' Arturo Escobar described the development discourse as:

These relations - established between institutions, socioeconomic processes, forms of knowledge, technological factors, and so on - define the conditions under which the objects, concepts, theories and strategies can be incorporated into the discourse. In sum, the system of relations establishes a discursive practice that sets the rules of the game: who can speak from what points of view, with what authority, and according to what criteria of expertise; it sets the rules that must be followed for this or that problem, theory or object to emerge and be named, analyzed, and eventually transformed into a policy or a plan. (cited in Rahnema and Bawtree, 1997: 87)

Escobar presented development discourse as a space in which development leaders set the rules and define statuses that do not appear to leave much freedom of expression and autonomy to the subjects of development. The subaltern conditionality of the subjects of development is, hence, consolidated. For Escobar, the coherence of effects that international development achieved is critical to its success as a hegemonic and repressive form of representation where the poor are universal preconstituted subjects deprived of the complexity and diversity of their societies: 'so that a squatter in Mexico city, a Nepalese peasant, and a Tuareg nomad become equivalent to each other as just poor and underdeveloped' (Rahnema and Bawtree, 1997: 92-93). Therefore, acknowledging a postcolonial need for dignity really matters in the construction of a more effective and consistent international development discourse respectful of dignity and autonomy. Suggesting a postcolonial need for dignity does not imply that people from formally colonized societies are more entitled to dignity in any way; but rather, it means that their colonial experience and its lasting effects on their lives after independence, through development programs for instance, engage dignity concerns when their former masters try to 'help' them.

\section{Dignition: Postcolonial politics of dignity}

Frantz Fanon, a Martinique-born psychiatrist who supported the Algerian struggle against French colonialism, is a key thinker of postcolonialism. His book The Wretched of the Earth and specifically his chapter 'On Violence' is considered critically influential 
for the liberation movements. Fanon, in the above mentioned chapter, told us the following about dignity:

For a colonized people the most essential value, because the most concrete, is first and foremost the land: the land which will bring them bread and, above all, dignity. But this dignity has nothing to do with the dignity of the human individual: for that human individual has never heard tell of it. All that the native has seen in his country is that they can freely arrest him, beat him, starve him: and no professor of ethics, no priest has ever come to be beaten in his place, nor to share their bread with him. (Fanon, 1963: 44)

Fanon talked about the Algerian context and showed that an individual's understanding of dignity, which was associated with western modern philosophical thought, was not applied by the European colonizers. The colonized were treated with all but dignity. Later on in his chapter, Fanon continued by saying that 'it is true to say that independence has brought moral compensation to colonized peoples, and has established their dignity. But they have not yet had time to elaborate a society, or to build up and affirm values' (1963: 81). This apparent 'immaturity' of newly independent societies that Fanon pointed out could be the result of the conflicting streams that North African societies were faced with: mainly a struggle between a seemingly misunderstood dignity, and a need for defiance and recognition, or what I call 'dignition.'

Is dignity limited to the material conception in postcolonial societies? How much of this conception of dignity is influenced by the colonial experience? If dignity was associated with land in the Algerian context as Fanon reported, this conception is certainly contradictory with the Islamic fundamentals of Algerian society, where dignity is associated with the intrinsic value of human beings as images of God (similar to Judeo-Christian fundamentals). Therefore, Fanon's description of dignity mandates the question: Was the understanding of dignity altered by the colonial experience? In the cases of 1956 and 2011 Egypt, the politics of dignity were particularly and dangerously powerful because they were presented as the need for recognition of the disenfranchised.

The postcolonial period started with the rise of independence movements in European colonies after the Second World War. In this period, the officialization of dignity as an international and universal human right also became clear in 1948, with the Universal Declaration of Human Rights. Michael Rosen in his analysis of dignity argued that the idea of dignity as a human right has drawn attention away from an essential sense of dignity, which is 'the right to be treated with dignity, that is, with proper respect' (Rosen, 2012). So, could an institutionalization of dignity undermine a 'communitarian' sense of dignity (i.e. treating people with dignity)?

The postcolonial context presents dilemmas when thinking about dignity: is dignity material or transcending? In both cases, one can argue that the colonial experience assaulted these dignities. The colonizers appropriated the land of the indigenous and attempted to alienate indigenous cultures and spirits, by claiming that they were 'uncivilized.' Particularly, Arjun Appadurai's work suggested a confinement of the subaltern. He argued against Dumont's work on hierarchy in India and showed that the problem is a tendency to exoticize and to totalize it as a tradition from Hegel's Geist (spirit) of an age. The consequence is to depict the whole of India under the system of caste for 
instance, when there are many more considerations that need to take place (Appadurai, 1988). As Taylor argued, this colonial misrecognition sparks a strong desire for recognition as an expression of dignity by the natives who hunger to regain and re-experience the idea of 'dignition.'

Gramsci's concern with 'hegemony' as a critique of capitalist society presented the inherent need for self-consciousness. Postcolonialist Hamid Dabashi (2012) argued that the Arab Spring demonstrated the rise of self-consciousness in postcolonial societies. WEB Du Bois's (1965) work also comes to mind in such a discussion, as he argued that emancipation and self-consciousness came from the experience of slavery. These are important considerations in arguing for a need for dignity, especially its recognition in postcolonial societies.

\section{Conclusion}

The 1956 nationalization of the Suez Canal under Nasser and the 2011 Egyptian Revolution in the midst of the Arab Spring were two inspiring events that showed a recurring call for dignity by the Egyptian people. This call unveiled the important social nature of the call for dignity that stemmed from a social malaise linked to economic and political disempowerment and oppression. It was a national need for dignity that trickled down into individual needs for dignity. These needs for dignity mixed with politics of recognition can be called 'dignition,' and refer to a particular postcolonial context. This context emerged from the European colonial experience that saw the expression of a native nationalism as a quest for the Self at the level of a nation. Such a context also marked the ruling of a hegemonic capitalism under which newly independent countries are confined to the periphery, resulting in the serious deterioration of social indicators. In this study of the postcolonial politics of dignity, both the Suez Canal nationalization and the 2011 Egyptian Revolution were moments when the marginalized rose to speak for themselves. This study has examined how the conception of dignity evolved between these two events and explored what the implications are for the consequent understanding of dignity. One outcome is that the conception of dignity is quite similar in these two events and speaks to the centrality of the legacy of colonialism in Egyptian society. However, one may ask why the experience from the Suez Canal nationalization on the need for dignity was forgotten and led to the re-emergence of the call for dignity in 2011. The problems appear to relate to various development issues and apparent poverty cycles that most developing countries have been subject to since their independence, and resemble an 'indignity trap.' In this case, one can consider the cause in an international community overall hostile to the idea that genuine sustainable equality should be granted to all countries and for their people's dignity. If nations are not considered equally within the greater international community, then how can individuals in turn be expected to be treated equally within their nations? If these two events speak to the desire and the power of the dignity call, their subsequent failures in uniting different factions of Egyptian society prove, on the other hand, the powers of humiliation and oppression that impede the establishment of a dignitarian society and a dignitarian world. 


\section{Acknowledgements}

Thanks to Bon C Cheng, Jeffrey T Martin, Tawanda S Nyawasha, and Didier Bigo for the discussions and editing. All errors and conclusions remain mine.

\section{Funding}

This research received no specific grant from any funding agency in the public, commercial, or not-for-profit sectors.

\section{Notes}

1. Khedive of Egypt and Sudan from 1863 to 1879.

2. General Naguib (who led the revolution) was forced to leave power due to disagreements with, at the time, Colonel Nasser. He was also under house arrest for 18 years until his release by President Anwar Sadat in 1972.

3. 'The Egyptian Revolution: First impressions from the field'; at: www.pdx.edu/ sociologyofislam/egyptian-revolution-first-impressions-field-mohammed-bamyeh

4. 'The Egyptian Revolution: First impressions from the field'; at: www.pdx.edu/sociologyofislam/egyptian-revolution-first-impressions-field-mohammed-bamyeh, emphasis added.

5. 'Mubarak faces Egypt protests on "Day of Rage" ' (Maggie Michael, 5 January 2011); at: www.huffingtonpost.com/2011/01/25/mubarak-faces-egypt-prote n 813572 .html

6. 'The Egyptian Revolution: First impressions from the field'; at: www.pdx.edu/ sociologyofislam/egyptian-revolution-first-impressions-field-mohammed-bamyeh

7. From 'The Muslim Brotherhood and the Egyptian society,' IkhwanWeb; at: www.ikhwanweb.com/article.php?id=806\&ref=search.php

8. From 'History of the Muslim Brotherhood in Egypt,' IkhwanWeb; at: www.ikhwanweb.com/ article.php?id=799\&ref $=$ search.php

9. Rankism refers to abusive behavior and relationships stemming from a position of power.

10. This verse is part of the Tunisian National Anthem that the former President of Tunisia, Zine El Abidine Ben Ali, imposed when he took office in 1987 after a bloodless coup d'etat. The irony is that this verse was chanted against him when he fled Tunisia during the Jasmine Revolution in 2011.

\section{References}

Al Messiri A (1989) Al-Intifada al falastiniyyat wa al-azmat a-sahyuniyyat: Dirasat fi al-Idraak wa al-Karamat. Cairo: al-Matba'a al-Fania.

Appadurai A (1988). Putting hierarchy in its place. Cultural Anthropology 3(1): 36-49.

Bamyeh MA (2009) Anarchy as Order: The History and Future of Civic Humanity. Lanham, MD: Rowman and Littlefield.

Calhoun C, Gerteis J, Moody J et al. (2012) Classical Sociological Theory. Chichester: WileyBlackwell.

Chesneaux J (1991) From East-West to North-South: From a North-South to a planetary perspective. Global Change, Peace and Security 3(1): 88-97.

Cicero MT (2004). De inventione. Whitefish, MT: Kessinger Publishing.

Dabashi H (2012) The Arab Spring: Delayed Defiance and the End of Postcolonialism. London: Zed Books.

Du Bois WEB (1965) The Souls of Black Folk. London: Longman.

Edkins J (2000) Whose Hunger? Concepts of Famine, Practices of Aid. Minneapolis and London: University of Minnesota Press. 
Fanon F (1963) The Wretched of the Earth. Harmondsworth: Penguin.

Ferguson N (2008). The Ascent of Money: A Financial History of the World. London: Penguin. Frank AG (1966) The Development of Underdevelopment. Boston, MA: New England Free Press. Fuller RW (2006) All Rise: Somebodies, Nobodies, and the Politics of Dignity. San Francisco: Berrett-Koehler Publishers.

Haq M ul (1995) Reflections on Human Development: How the Focus of Development Economics Shifted from National Income Accounting to the People-centered Policies, Told by One of the Chief Architects of the New Paradigm. New York: Oxford University Press.

Ho AHY et al. (2013) Living and dying with dignity in Chinese society: Perspectives of older palliative care patients in Hong Kong. Age and Ageing 42(2): 455-461.

Hopwood D (1982) Egypt, Politics and Society, 1945-1981. London: Allen and Unwin. Horne A (2006) A Savage War of Peace: Algeria 1954-1962. New York: Review of Books.

Hourani AH and Ruthven M (2002) A History of the Arab Peoples. Cambridge, MA: Belknap Press of Harvard University Press.

Ibrahim SE (1996) Reform and frustration in Egypt. Journal of Democracy 7(4): 125-135.

Inglehart R (1971) The silent revolution in Europe: Intergenerational change in post-industrial societies. American Political Science Review 65(4): 991-1017.

Jamoul L (2004) Palestine - in search of dignity. Antipode 36(4): 581-595.

Kant I (2008) On the Metaphysics of Morals and Ethics. Radford, VA: Wilder Publications.

Kyle K (2011 [1991]) Suez: Britain's End of Empire in the Middle East. London: I. B. Tauris.

Manley M (1982) Jamaica: Struggle in the Periphery. London: Third World Media.

Mead GH (1967) Mind, Self, and Society: From the Standpoint of a Social Behaviorist (Works of George Herbert Mead, Vol. 1). Chicago: University of Chicago Press.

Nussbaum MC (2009) Creating capabilities: The human development approach and its implementation. Hypatia 24(3): 211-215.

Nussbaum M and Sen A (1993) The Quality of Life. Oxford: Oxford University Press.

Rahnema M and Bawtree V (1997) The Post-development Reader. London: Zed Books.

Rosen M (2012) Dignity: Its History and Meaning. Cambridge, MA: Harvard University Press.

Sen AK (1999) Development as Freedom. Oxford: Oxford University Press.

Taylor C (1997) The politics of recognition. In: Heble A, Pennee DP and Struthers JR (eds) New Contexts of Canadian Criticism. Peterborough, ON: Broadview Press, pp. 98-131.

Tilly C (1980) Historical sociology. Current Perspectives in Social Theory 29(1): 55-59.

Wallerstein I (1996) The interstate structure of the modern world-system. In: Smith S, Booth K and Zalewski M (eds) International Theory: Positivism and Beyond. Cambridge: Cambridge University Press, pp. 87-107.

Werker AL (director) (1934) The House of the Rothschild.

Young R (2003) Post-colonialism: A Very Short Introduction. Oxford: Oxford University Press.

\section{Author biography}

Zaynab El Bernoussi teaches at the School of Humanities and Social Sciences, Al Akhawayn University. She started her doctoral studies in international relations at the University of Hong Kong and is now continuing her program at the Catholic University of Louvain, Belgium.

\section{Résumé}

Cet article est une étude sur la dignité et la politique de la dignité dans l'Égypte postcoloniale, axée sur l'historicité et le contexte socio-économique de deux évènements : la crise du Canal de Suez de 1956, à l'époque de la montée du nationalisme qui a suivi l'indépendance, et la révolution 
égyptienne de 20I I, pendant le Printemps arabe. Dans l'article, est analysée l'importance du concept de dignité en philosophie et dans les sciences sociales, en particulier concernant le développement et le besoin postcolonial de dignité (dignity) et de reconnaissance (recognition), que l'auteur désigne par le terme de « dignition ». La question centrale ici est de savoir comment la notion de dignité a évolué entre ces deux évènements et quelles en sont les implications pour la compréhension de la dignité.

\section{Mots-clés}

Développement, Égypte, philosophie, politiques de la dignité, sociologie historique

\section{Resumen}

Este artículo es un estudio sobre la dignidad y la política de la dignidad en el Egipto postcolonial, y se centra en la historicidad y el origen socioeconómico de dos eventos: la crisis del Canal de Suez en 1956 durante el auge del nacionalismo posterior a la independencia y la revolución egipcia de 20I I, durante la Primavera Árabe. El estudio analiza la importancia del concepto de dignidad en la filosofía y en las ciencias sociales, y específicamente en relación con el desarrollo y la necesidad postcolonial de dignidad y reconocimiento, que el autor denomina "dignition". La cuestión central del trabajo es cómo ha evolucionado la concepción de la dignidad entre los dos eventos y cuáles son las implicaciones para la consiguiente comprensión de la dignidad.

\section{Palabras clave}

Desarrollo, Egipto, filosofía, políticas de dignidad, sociología histórica 